\title{
Effects of Silica Addition on the Chemical, Mechanical and Biological Properties of a New $\alpha$-Tricalcium Phosphate/Tricalcium Silicate Cement
}

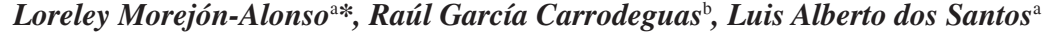 \\ ${ }^{a}$ Departamento de Materiais, Escola de Engenharia, \\ Universidade Federal do Rio Grande do Sul - UFRGS, Porto Alegre, RS, Brazil \\ ${ }^{b}$ Departamento de Cerámica, Instituto de Cerámica y Vidrio - CSIC, Madrid, Spain
}

Received: January 28, 2011; Revised: August 14, 2011

\begin{abstract}
The addition of tricalcium silicate $\left(\mathrm{C}_{3} \mathrm{~S}\right)$ to apatite cements results in an increase of bioactivity and improvement in the mechanical properties. However, adding large amounts raises the local $\mathrm{pH}$ at early stages, which retards the precipitation of hydroxyapatite and produces a loss of mechanical strength. The introduction of Pozzolanic materials in cement pastes could be an effective way to reduces basicity and enhance their mechanical resistance; thus, the effect of adding silica on the chemical, mechanical and biological properties of $\alpha$-tricalcium phosphate/ $\mathrm{C}_{3} \mathrm{~S}$ cement was studied. Adding silica produces a reduction in the early $\mathrm{pH}$ and a decrease in setting times; nevertheless, the presence of more calcium silicate hydrate $(\mathrm{C}-\mathrm{S}-\mathrm{H})$ delays the growth of hydroxyapatite crystals and consequently, reduces early compressive strength. The new formulations show a good bioactivity, but higher cytotoxicity than traditional cements and additions higher than $2.5 \%$ of $\mathrm{SiO}_{2}$ cause a lack of mechanical strength and an elevated degradability.
\end{abstract}

Keywords: calcium phosphate cements, hydroxyapatite, tricalcium silicate, pozzolan

\section{Introduction}

Calcium phosphate cements (CPCs) are a clinical alternative to traditional bioceramics because they are easy to handle and shape, mold themselves well to the contours of defective surfaces, and set in situ in the bone cavity to form a solid restoration ${ }^{1}$. Since their development in the mid-80's, CPCs have also attracted great interest due to their chemical similarity to the mineral phase of bone tissue and their good osteoconductivity ${ }^{2}$.

One of the most important formulations is based on $\alpha$-tricalcium phosphate $\left[\alpha-\mathrm{Ca}_{3}\left(\mathrm{PO}_{4}\right)_{2} ; \alpha-\mathrm{TCP}\right]$, which sets in situ and forms a calcium-deficient hydroxyapatite $\left[\mathrm{Ca}_{9}\left(\mathrm{HPO}_{4}\right)\left(\mathrm{PO}_{4}\right)_{5}(\mathrm{OH})\right.$; CDHA] when hydrated ${ }^{3}$. However, it is not very strong under compression ${ }^{4}$ and its mechanical strength is low when compared to that of cortical bone ${ }^{5}$, limiting its application to areas subjected to low mechanical loads ${ }^{6}$.

In view of the excellent bioresorbability of CDHA, researchers have focused their efforts on overcoming the mechanical weakness of calcium phosphate cements by using different fillers, fibers and reinforcing additives that lead to the formation of various multiphase composites, based on the idea that the filler in the matrix may eliminate crack propagation ${ }^{7}$. Nevertheless, the presence of fillers prevents bone ingrowths into pores and produces a denser cement with a slower resorption rate and hence a slower bone substitution ${ }^{8}$. Therefore, it is difficult to increase the strength of these cements without negatively affecting other properties.

Due to their spontaneous development of strength (spontaneous consolidation) towards water", the addition of $\mathrm{Ca}_{3} \mathrm{SiO}_{5}\left(\mathrm{C}_{3} \mathrm{~S}\right)$ to the $\alpha$-TCP-based cement could be an effective way to increase its mechanical strength ${ }^{10}$ and improve the bioactivity and biocompatibility of traditional CPCs ${ }^{11,12}$. However, the $\mathrm{pH}$ increase during the initial stages delays setting times and prevents apatite formation in larger concentrations.

In the chemistry of ordinary Portland cement (OCP), synthetic colloidal silica (silica fume) is a highly reactive siliceous material which reacts with the calcium hydroxide formed in hydrated cement paste (pozzolan). Although the mechanisms by which silica fume operates are unclear, the presence of small amounts of silica can accelerate the hydration of $\mathrm{C}_{3} \mathrm{~S}$ by forming colloidal calcium silicate hydrate $(\mathrm{C}-\mathrm{S}-\mathrm{H})$, thereby increasing the rate of early strength gain ${ }^{13}$.

Thus the aim of this work was to study the effects of adding silica on the chemical, mechanical and biological properties of $\alpha-\mathrm{TCP} / \mathrm{C}_{3} \mathrm{~S}$ cement after ageing in simulated body fluid (SBF).

\section{Experimental}

\subsection{Materials}

To prepare the $\alpha-\mathrm{TCP} / \mathrm{C}_{3} \mathrm{~S} / \mathrm{SiO}_{2}$ cement, all chemicals of analytical grade were used.

$\alpha$-TCP was prepared through solid state reaction, heating the appropriate mixture of $\gamma-\mathrm{Ca}_{2} \mathrm{P}_{2} \mathrm{O}_{7}$ (Extra Pure, Dyne ${ }^{\circledR}$ ) and $\mathrm{CaCO}_{3}$ (Extra Pure, Nuclear) at $1300^{\circ} \mathrm{C}$ for 5 hours followed by quenching in air $^{14}$. After calcination, the product was wet milled for 4 hours in a polyethylene jar with alumina balls using an alcoholic medium (anhydrous ethanol, 99.5\%, Cromoline) to an average particle size inferior to $10 \mu \mathrm{m}$.

Tricalcium silicate powders were synthesized by sol-gel route, using $\mathrm{Ca}\left(\mathrm{NO}_{3}\right)_{2} \cdot 4 \mathrm{H}_{2} \mathrm{O}$ and $\mathrm{Si}\left(\mathrm{OC}_{2} \mathrm{H}_{5}\right)_{4}(\mathrm{TEOS})^{15}$. Briefly, suitable amount of TEOS was added in $200 \mathrm{~mL}$ water under continuous stirring and then, required amount of $\mathrm{Ca}\left(\mathrm{NO}_{3}\right)_{2} \cdot 4 \mathrm{H}_{2} \mathrm{O}$ was added to the solution. The solution was maintained at $60^{\circ} \mathrm{C}$ until gelation occurred and the gel was dried at $120^{\circ} \mathrm{C}$. Repeated grindings and calcinations at $1400{ }^{\circ} \mathrm{C}$ were necessary to reach the product as monophasic as possible. In order to obtain powders with similar average particle size, the same milling treatment as in the case of $\alpha$-TCP was used. 


\subsection{Preparation of composite samples}

Synthesized $\mathrm{C}_{3} \mathrm{~S}(7.11 \mu \mathrm{m})$ was mixed with $\alpha$-TCP $(10.71 \mu \mathrm{m})$ in powder ratios of $0,5.0$ and 10.0 mass $\%$ and precipitated silica WL180 (Auriquímica Ltda - Brazil) (surface area $133 \mathrm{~m}^{2} \cdot \mathrm{g}^{-1}$ and mean diameter $19.54 \mu \mathrm{m}$ ) was added in a molar ratio $\mathrm{SiO}_{2}: \mathrm{C}_{3} \mathrm{~S}=2$. The liquid phase was a sodium phosphate buffer prepared from $\mathrm{NaH}_{2} \mathrm{PO}_{4}$ and $\mathrm{Na}_{2} \mathrm{HPO}_{4} \cdot 12 \mathrm{H}_{2} \mathrm{O}$, and the liquid-to-powder ratio $(\mathrm{L} / \mathrm{P})$ was dependent of the content of $\mathrm{C}_{3} \mathrm{~S}$ added ranging from 0.4 to $0.44 \mathrm{~mL} \cdot \mathrm{g}^{-1}$. Each powder sample was carefully weighed and mixed with the liquid phase in appropriate powder-to-liquid ratio, packed into silicon molds and aged at $36.5^{\circ} \mathrm{C}$ with controlled humidity for 24 hours. The samples were identified as $\alpha-\mathrm{TCP}, 5 \mathrm{SiO}_{2}$ and $10 \mathrm{SiO}_{2}$ being the number the quantity of $\mathrm{C}_{3} \mathrm{~S}$ added in mass percent.

\subsection{Setting time measurement}

Setting time of samples was measured according to ASTMC266-89 using a Gillmore Needles method ${ }^{16}$. Three specimens for each formulation were tested and standard deviation was used as a measure of the standard uncertainty. Initial setting time was determined as the end of moldability without serious damage to the cement structure and the final setting time as the time beyond which it is possible to touch the cement without causing serious damage.

\subsection{In vitro tests}

To assess in vitro bioactivity, the 24 hours-set pastes were soaking in simulated SBF at $36.5^{\circ} \mathrm{C} \mathrm{SBF}^{17}$ for 14 days and afterward, gently rinsed with deionized water followed by ethanol dehydration and drying in atmospheric temperature.

The degradation behavior was characterized by monitoring changes in weight loss in $\mathrm{SBF}^{18}$. For degradability test, the disks were accurately weighed before and after immersion in SBF. The weight loss (WL) was calculated according to Equation 1 being $\mathrm{W}_{0}$ the initial weight of the specimen and $\mathrm{W}_{\mathrm{d}}$ the weight of the specimen dried after different degradation times (7,14 and 21 days). Each measurement was performed three times and the average value was calculated.

$$
W L \%=\frac{\left(W_{0}-W_{d}\right)}{W_{0} \times 100}
$$

\subsection{Cytotoxicity test for cements}

The cell viability assay was performed by direct contact test according to the ISO 10993-5 (Biological evaluation of medical Part 5: Tests for in vitro cytotoxicity) using peripheral blood mononuclear cells (PBMCs) and the MTT assay.

The PBMCs were assembled cultured in a Dulbecco's modified Eagle's Medium (DMEM) (Sigma) with HEPES (Sigma) (free acid, 2.5-3.7 g.L L $^{-1}$ ) supplemented with $10 \%$ fetal bovine serum (FBS) (Cultilab, Sao Paulo, Brazil), at $37{ }^{\circ} \mathrm{C}$ in a humidified atmosphere of $5 \% \mathrm{CO}_{2}$ for one 24 and 48 hours. The dissolution extracts were prepared adding the culture medium to cement discs previously incubated in SBF for 7 days, placed in a 24-well plates and sterilized by ethylene oxide. The cell suspension was adjusted to a density of $10^{5}$ cells in $0.5 \mathrm{~mL}$ of HDMEM and was added to each well of a 24-well plate. As negative control, conventional $\alpha$-TCP, also incubated in SBF for 7 days was used ${ }^{19}$.

The number of viable cells was quantitatively assessed by MTT test. After incubating at $37^{\circ} \mathrm{C}$ and $5 \% \mathrm{CO}_{2}$ for 24 and 48 hours, $150 \mu \mathrm{L}$ of $3 \mathrm{mg} . \mathrm{mL}^{-1} 3$-(4,5-dimethylthiazol-2-yl)-2,5-diphenyl tetrazolium bromide (MTT) solution was added to extract/cell constructs and cultured for 3 hours at $37{ }^{\circ} \mathrm{C}$. Then $100 \mu \mathrm{L}$ of dimethyl sulfoxide (DMSO) was added to each well, and the product was colorimetrically assessed with a Model Multiskan EX Microplate Reader (Labsystems, USA). Absorbances were read at a wavelength of $540 \mathrm{~nm}$.
Experimental values were analyzed via one-way ANOVA test follow by Tukey's Multiple Comparison Test.

\subsection{Characterization techniques}

Phase composition of the samples was determined by X-Ray Diffraction (XRD) in a PHILLIPS ${ }^{\circledR}$ diffractometer (X'Pert MPD) and $\mathrm{Cu}$-target. Diffractograms were recorded employing Ni-filtered radiation $(\lambda=1.5406 \AA)$ with a step size of $0.05^{\circ}$ and a time/step ratio of 1 second.

Morphological variations before and after soaking in SBF were characterized by Scanning Electron Microscopy (SEM) using a JEOL microscope (JSM-6060) on gold-coated samples.

Compressive strength (CS) was measured in servohydraulic Universal Testing Machine (MTS 810) with a load measuring cell of $10 \mathrm{kN}$ and a loading rate of $1 \mathrm{~mm} / \mathrm{min}$. The number of replicas was $\mathrm{n}=10$ and Student Multiple Comparison Test was used to compare mean values.

$\mathrm{pH}$ measures were carried out during soaking in SBF and lectures were made in an $\mu \mathrm{PA}-210 \mathrm{pH}$ meter at $36,5^{\circ} \mathrm{C}$.

\section{Results and Discussion}

Figure 1 shows the X-ray of silica powder used in different formulations. The results showed a mixture of different polymorphs in addition to amorphous form; even though that the only stable form under normal conditions is $\alpha$-quartz and this is the form in which crystalline silicon dioxide is usually encountered. The phases found were: Cristobalite Low (JCPDS 76-0936); Tridymite M Low (JCPDS 76-0894); Quartz (JCPDS 79-1913); $\mathrm{SiO}_{2}$ (JCPDS 16-0980). The characterization of raw materials $\alpha-\mathrm{TCP}$ and $\mathrm{C}_{3} \mathrm{~S}$ was described in previous works. For $\alpha$-TCP powder, the presence of approximately $18 \% \beta-\mathrm{Ca}_{3} \mathrm{PO}_{4}(\beta-\mathrm{TCP})$, determined by quantitative analysis ${ }^{19,20}$, was found in addition to $\alpha$-TCP phase, due to the presence of $\mathrm{Mg}^{2+}$ in raw materials. In the case of $\mathrm{C}_{3} \mathrm{~S}$, the most intense characteristic peaks of $\mathrm{CaO}$ due to the decomposition of $\mathrm{Ca}_{3} \mathrm{SiO}_{5}$ were observed ${ }^{21}$.

The initial and final setting times of $\alpha$-TCP and the different composites are shown in Figure 2. The setting times of $\alpha$-TCP were higher than those reported in the literature for similar materials ${ }^{22}$ due

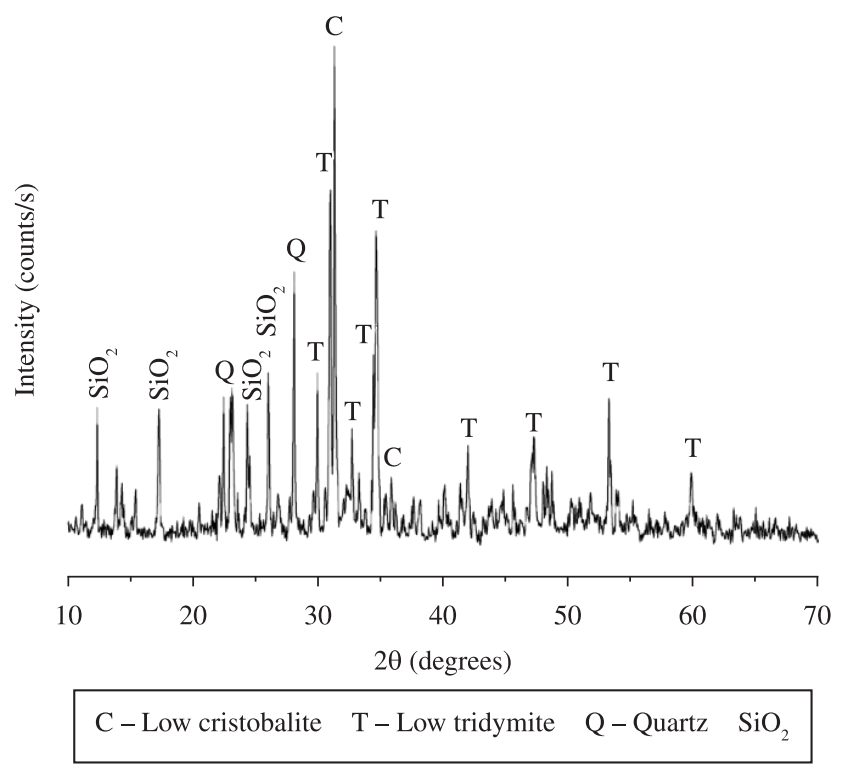

Figure 1. X-Ray diffraction patterns of $\mathrm{SiO}_{2}$ powder. 
to the presence of $\beta$-TCP in the starting powder that delays -TCP hydrolysis (Equation 2). When $\mathrm{C}_{3} \mathrm{~S}$ is added, a significant increase in setting times is observed in relation to traditional -TCP cement (more than 200 minutes for initial setting time and 400 minutes for final setting time) this being directly related to the content of $\mathrm{C}_{3} \mathrm{~S}$ added ${ }^{12}$. The presence of $\mathrm{SiO}_{2}$ reduces the setting time of the $\alpha$-TCP/C $\mathrm{C}_{3} \mathrm{~S}$ compositions with a $5 \%$ weight content of $\mathrm{C}_{3} \mathrm{~S}\left(5 \mathrm{SiO}_{2}\right)$; however, the values obtained are still higher than those for $\alpha$-TCP cements. Higher additions of $\mathrm{SiO}_{2}$ increased the setting time and are not suitable for immediate clinical applications ${ }^{23}$.

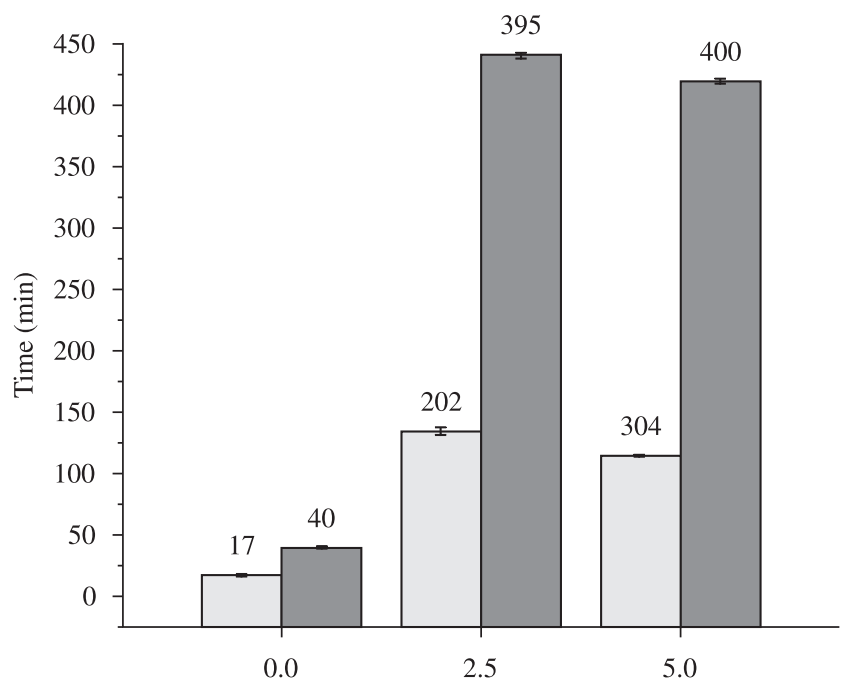

Weight ratio of $\mathrm{SiO}_{2}(\%)$

$\square$ Initial setting time $\square$ Final setting time

Figure 2. Initial and final setting time of the paste samples with different $\mathrm{SiO}_{2}$ contents $\left.(\mathrm{L} / \mathrm{P})=0.4 \mathrm{~mL} \cdot \mathrm{g}^{-1}\right)$.

$10 \mathrm{SiO}_{2}$

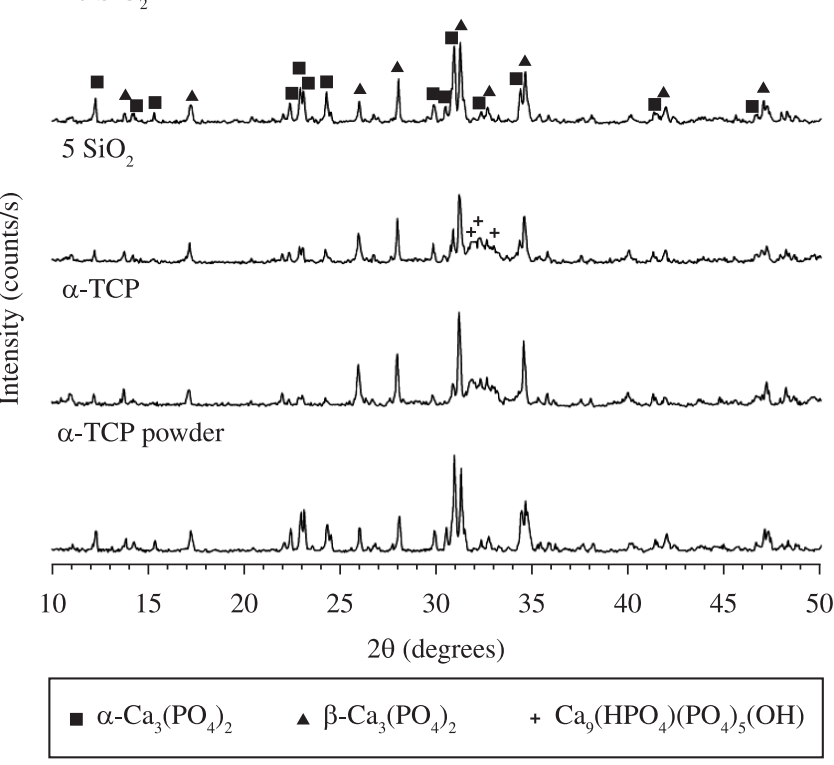

Figure 3. XRD patterns of cements 24 hours set.

$$
3 \alpha-\mathrm{Ca}_{3}\left(\mathrm{PO}_{4}\right)_{2(\mathrm{~s})}+\mathrm{H}_{2} \mathrm{O}=\mathrm{Ca}_{9}\left(\mathrm{HPO}_{4}\right)\left(\mathrm{PO}_{4}\right)_{5} \mathrm{OH}_{(\mathrm{s})}
$$

When $\mathrm{C}_{3} \mathrm{~S}$ is added, the solubility of $\alpha$-TCP decreases due to the formation of $\mathrm{Ca}(\mathrm{OH})_{2}$ and $\mathrm{C}-\mathrm{S}-\mathrm{H}$ during $\mathrm{Ca}_{3} \mathrm{SiO}_{5}$ hydrolysis (Equation 3); and setting times increase consequently. The addition of silica reduces the alkalinity of the medium by reacting with the $\mathrm{CaOH}_{2}$ formed (Equation 4), thus the setting times are reduced. Nevertheless, by increasing the amount of added $\mathrm{C}_{3} \mathrm{~S}$ and $\mathrm{SiO}_{2}$ $\left(10 \mathrm{SiO}_{2}\right)$, more dense calcium silicate gel $(\mathrm{C}-\mathrm{S}-\mathrm{H})$ is formed on the

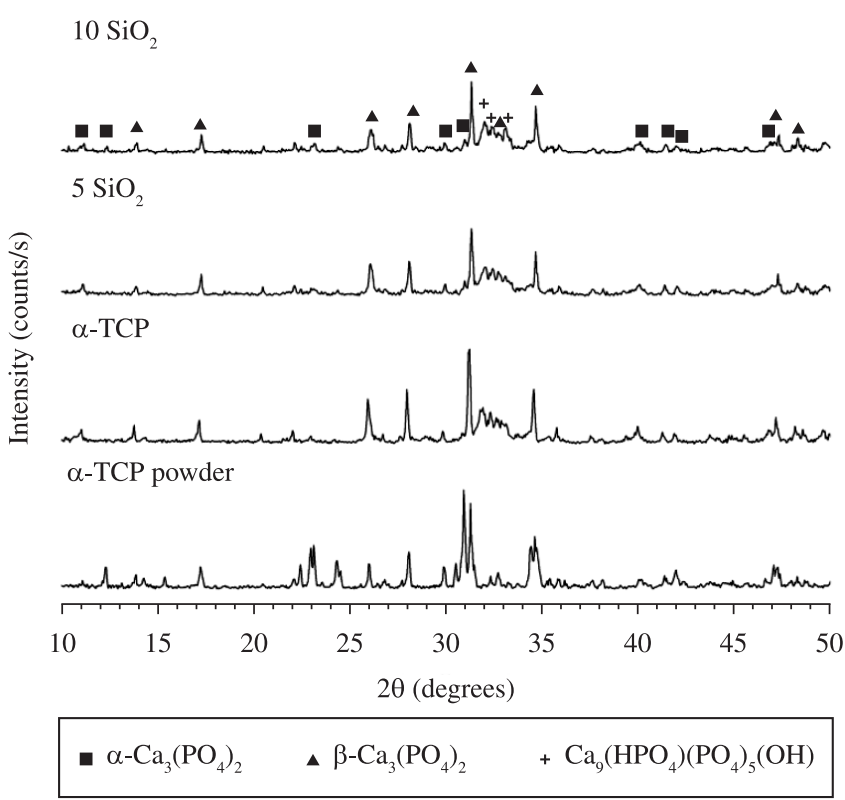

Figure 4. XRD patterns of cements after 7 days in SBF.

$10 \mathrm{SiO}_{2}$

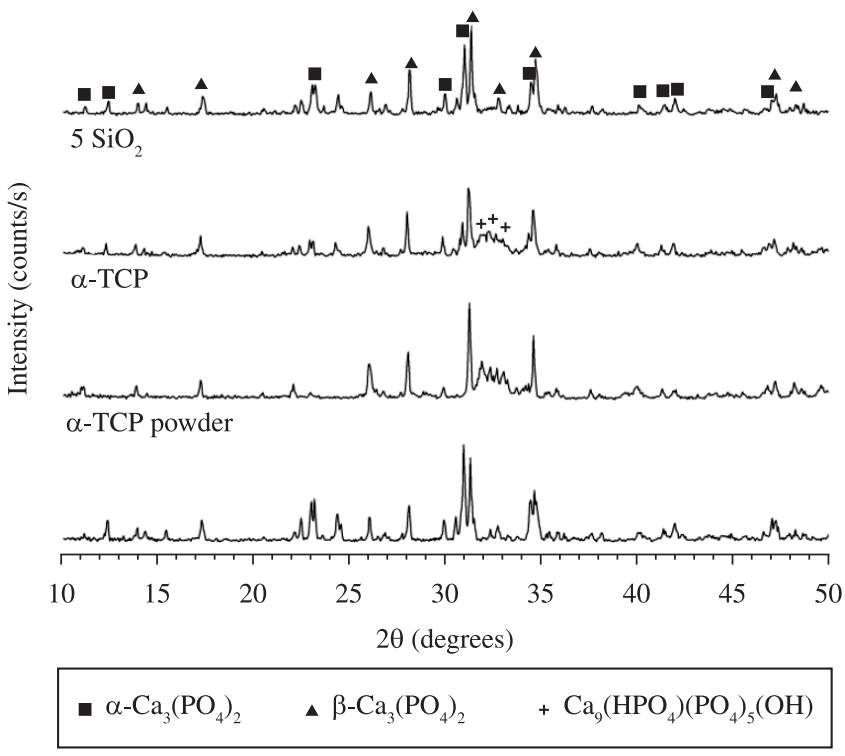

Figure 5. XRD patterns of cements after 14 days in SBF. 

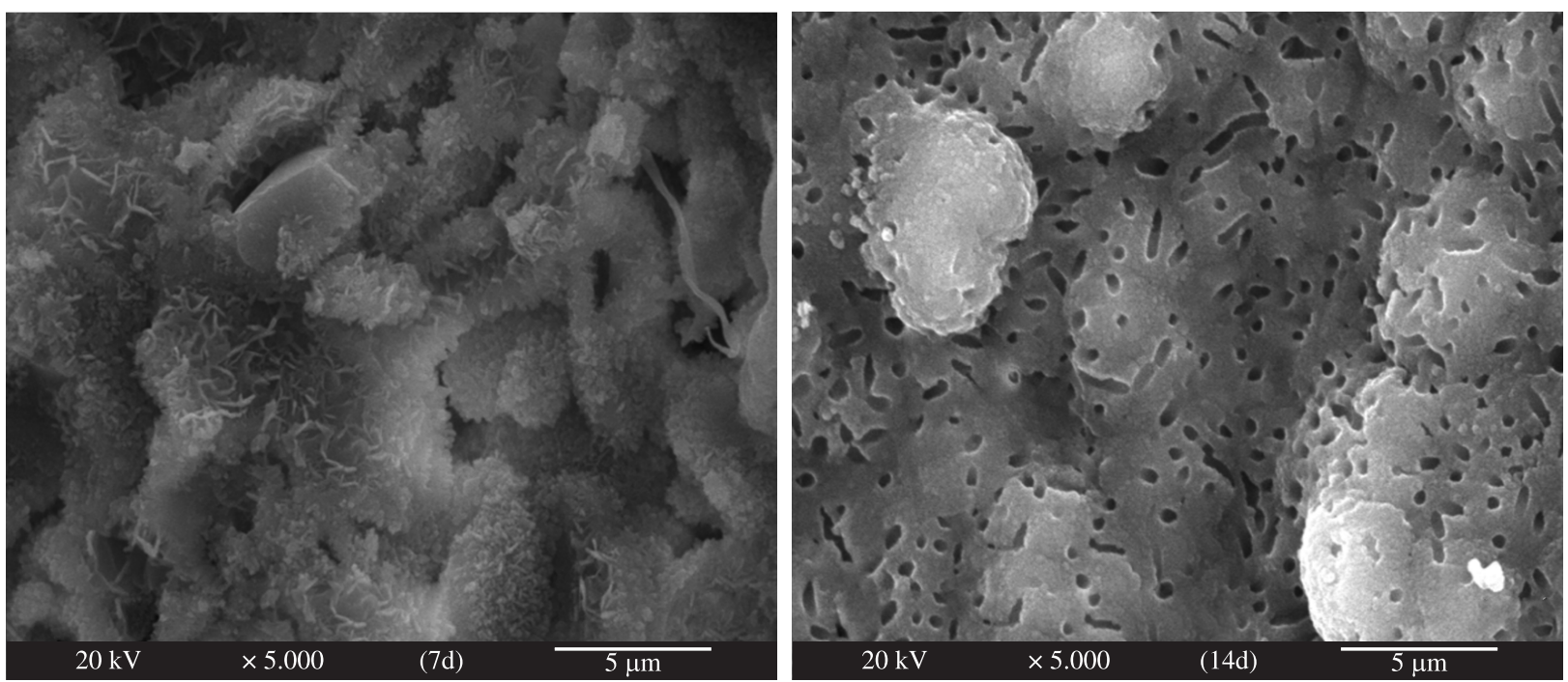

(a)
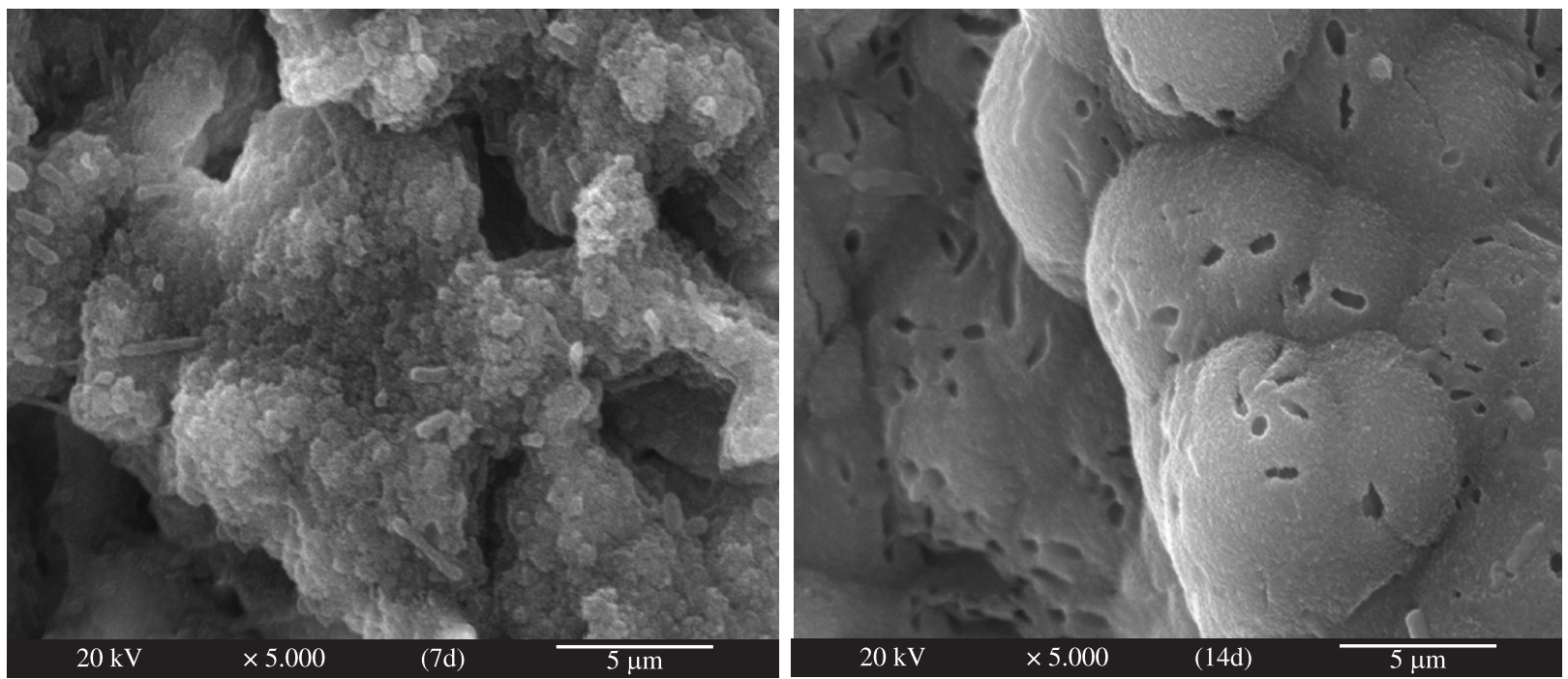

(b)
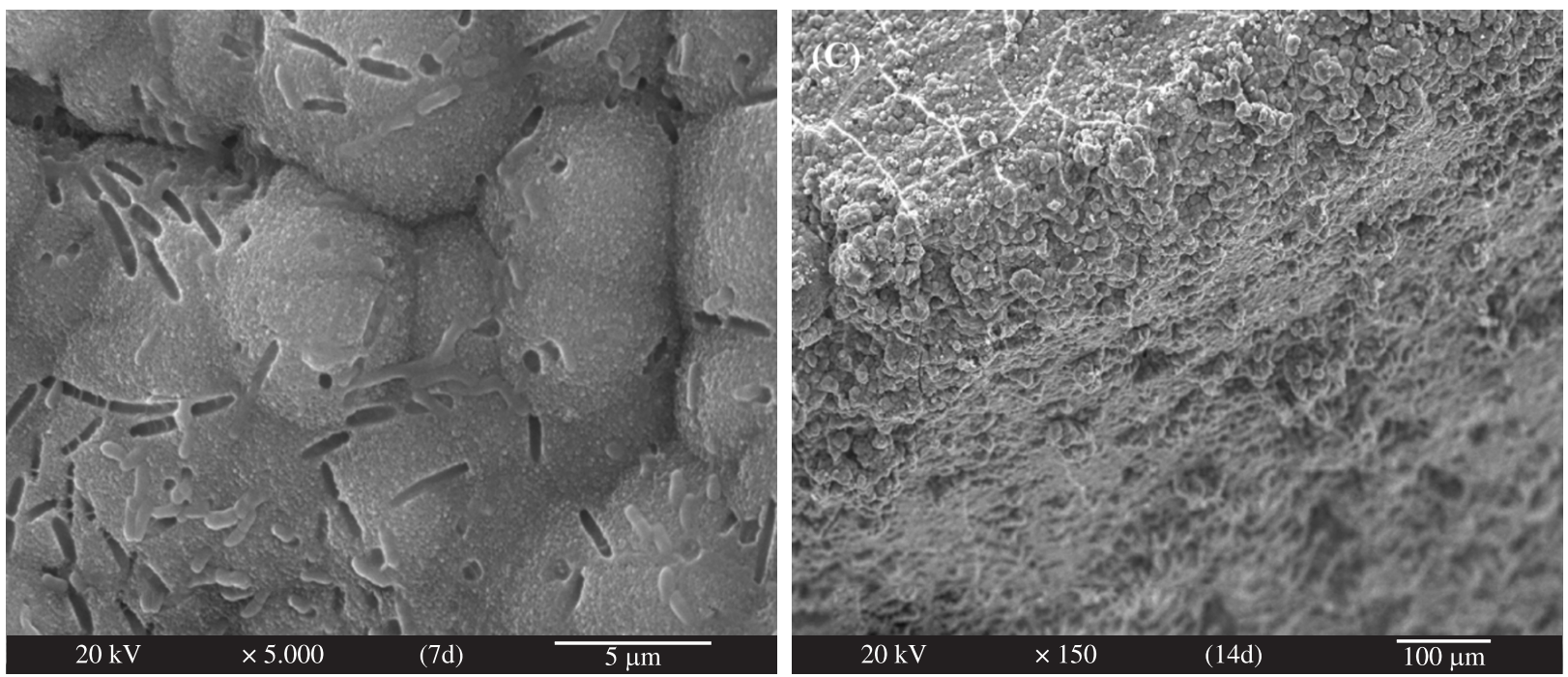

(c)

Figure 6. SEM micrographs of surface of a) $\alpha-\mathrm{TCP}$; b) $5 \mathrm{SiO}_{2}$; and c) $10 \mathrm{SiO}_{2}$ after soaking in $\mathrm{SBF}$ for 7 and $14 \mathrm{~d}$. 

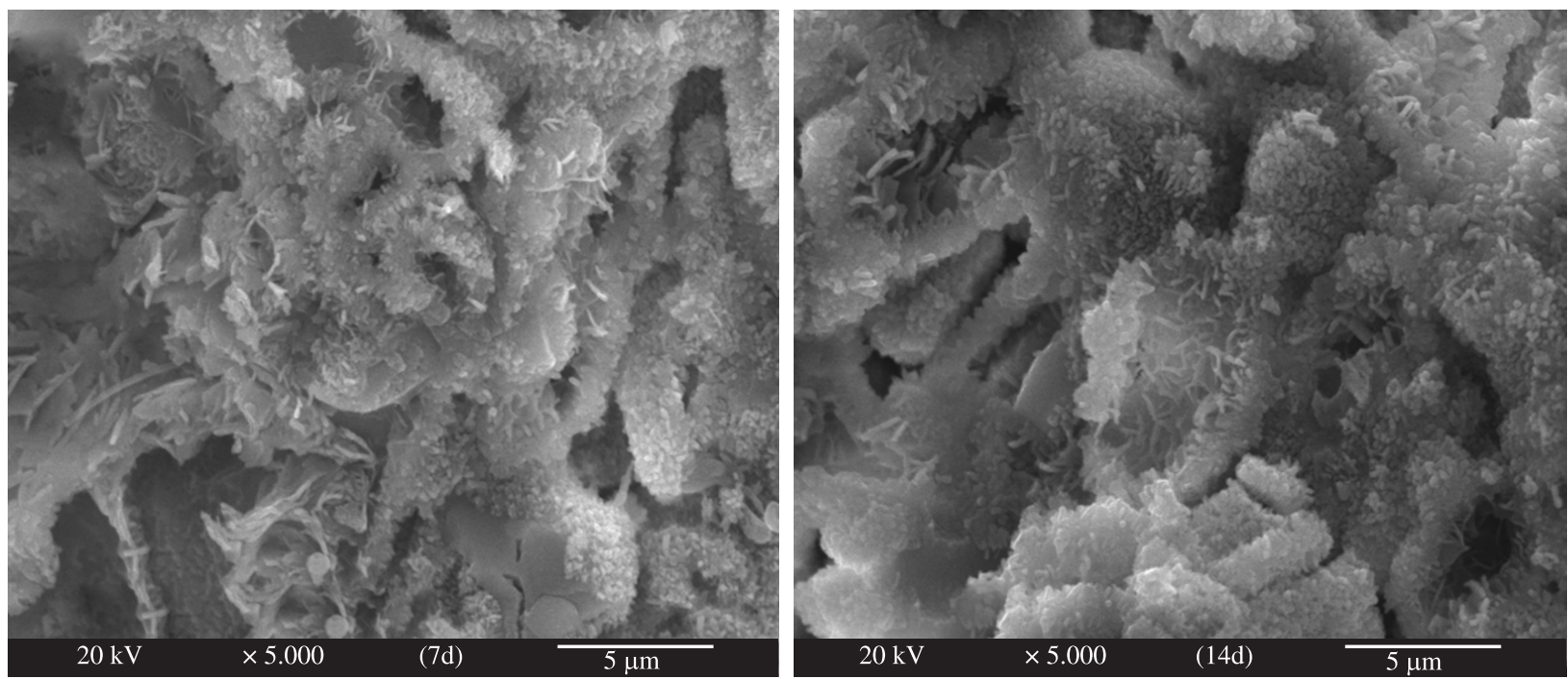

(a)
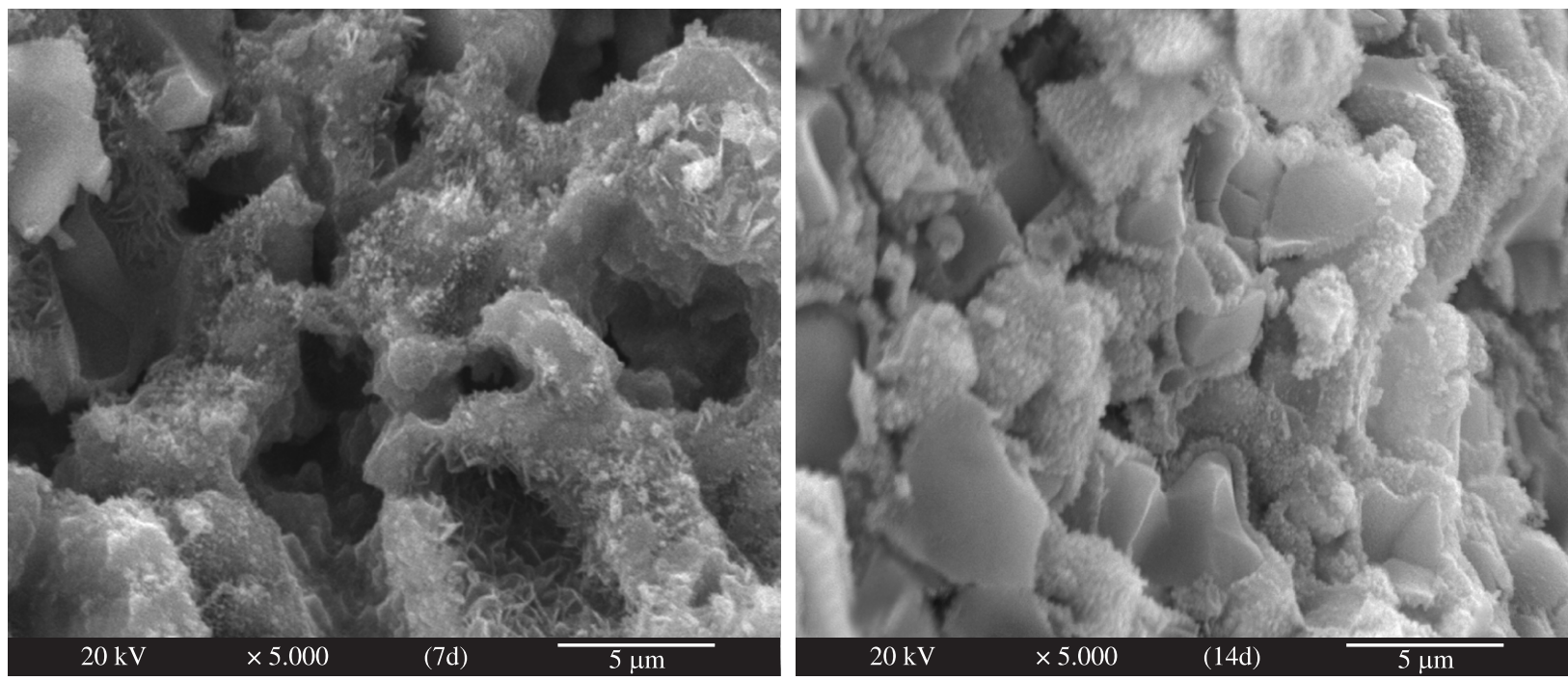

(b)


(c)

Figure 7. SEM micrographs of fracture surface of a) $\alpha-\mathrm{TCP}$; b) $5 \mathrm{SiO}_{2}$; and c) $10 \mathrm{SiO}_{2}$ after soaking in $\mathrm{SBF}$ for 7 and $14 \mathrm{~d}$. 
surface of $\alpha$-TCP particles preventing dissolution of the grains and precipitation of CDHA and increasing the setting times as a result.

$$
\begin{aligned}
& \mathrm{Ca}_{3} \mathrm{SiO}_{5(\mathrm{~s})}+3 \mathrm{H}_{2} \mathrm{O}=\mathrm{CaO} \cdot \mathrm{SiO}_{2} \cdot \mathrm{H}_{2} \mathrm{O}_{(\text {gel })}+2 \mathrm{Ca}(\mathrm{OH})_{2(\mathrm{~s})} \\
& \mathrm{Ca}(\mathrm{OH})_{2(\mathrm{~s})}+\mathrm{SiO}_{2(\mathrm{~s})}=\mathrm{CaO} \cdot \mathrm{SiO}_{2} \cdot \mathrm{H}_{2} \mathrm{O}_{(\text {gel })}
\end{aligned}
$$

The x-ray diffraction patterns of different composites before and after soaking in SBF are displayed in Figures 3-5. For $\alpha-T C P$, mainly peaks of CDHA (JCPDS 46-0905) were observed in addition to $\beta$-TCP (JCPDS 09-0169) peaks at all soaking times. The $\beta$-TCP is considered an impurity in the starting powders as it not involved in the hydration reaction and remains unreacted; this is why their most intense peaks appear with great intensity in all diffraction patterns.

After 24 hours setting (Figure 3), in composites containing $\mathrm{SiO}_{2}$, the X-ray diffraction peaks of CHDA appeared less intense, and unreacted -TCP (JCPDS 09-0348) were also detected as a result of the delay in the dissolution of the $\alpha$-TCP particles. The greater the amount of $\mathrm{C}_{3} \mathrm{~S} / \mathrm{SiO}_{2}$ added, the greater the intensity of the unreacted $\alpha$-TCP peaks and the lower the CDHA formed.

A few differences were observed in X-ray patterns of composites after 7 and 14 days of SBF soaking (Figures 4-5). The X-ray spectra of all formulations were very similar and the presence of CDHA, in addition to $\beta$-TCP and $\alpha$-TCP, was observed in all cases. However, owing to the limitations of the technique, it was not possible to differentiate between the hydroxyapatite precipitated from the $\alpha$-TCP and that obtained by precipitation in SBF, and observations of the surfaces and fracture surfaces by SEM were necessary to clarify this.

On the other hand, the presence of calcium-silicate-hydrate (C-S-H) was not detected, probably due to the low content on the sample and the amorphous character of these hydrates.

The observation by SEM is an effective way to estimate the bioactivity of materials as apatite grains and layers formed have differentiated features ${ }^{24}$; while several authors have considered the materials to be biocompatible judging from the presence or absence of a superficial layer of hydroxyapatite formed after immersion in simulated physiological solutions. Figure 6 shows the SEM images of $\alpha-\mathrm{TCP}, 5 \mathrm{SiO}_{2}$ and $10 \mathrm{SiO}_{2}$ after soaking in $\mathrm{SBF}$ for 7 and 14 days. For $\alpha$-TCP cement (Figure 6a) a network of entangled needle-like crystals or petal-like plates, typical for set $\alpha$-TCP-based calcium phosphate cements, was observed after 7 days of immersion, whereas a layer of bone-like apatite, precipitated under physiological conditions, was detected within 14 days of SBF soaking. Although measures were taken to maintain aseptic conditions, bacterial contamination by Bacillis and Cocci colonies was observed on samples surface ${ }^{25}$.

Adding small amounts of $\mathrm{SiO}_{2}$ produces a bumpy and amorphous appearance after 7 days (Figure 6b) and a homogeneous layer of CDHA with globular shape morphology, typical of bioactive materials after 14 days $^{26}$ immersed in SBF. The higher the silicon content in the composite, the shorter the time required for the formation of the surface layer (Figure 6c). No typical features of type I C-S-H ${ }^{27}$ were observed for silica additions maybe due to the large quantity of quartz present in the sample, since the $\mathrm{SiO}_{2}$ modification used has a decisive influence on the processes of formation of calcium silicate hydrates ${ }^{28}$.

Different microstructural features can be seen in the fracture surface of different composites (Figure 7). Since early stages, $\alpha-\mathrm{TCP}$ shows the typical petal-like plates covering the biggest grains and the growth of these plates with time, at the expense of smaller grains, within the interstices of fracture surface (Figure 7a). With low contents of $\mathrm{SiO}_{2}$ (Figure 7b) incipient precipitation of some CDHA crystals can be seen; crystals that grow with soaking time enclosing the larger $\alpha$-TCP grains. For further additions of $\mathrm{SiO}_{2}$ (Figure $7 \mathrm{c}$ ), no significant differences with soaking time were found and the cross section appeared covered or speckled with small distinct features that could be identified as small crystals of dry C-S- $\mathrm{H}^{29}$. No needle-like crystals or petal-like plates were observed ascribed to the lack of time for CDHA growth to occur besides insufficient time and conditions for the material to react completely.

With the presence of $\mathrm{C}_{3} \mathrm{~S}$ and $\mathrm{SiO}_{2}$, the $\mathrm{HSiO}^{3-}$ ions are released during the hydration of the composite paste, acting as sites for nucleation of apatite crystals and hence accelerating the deposition of apatite on the surface ${ }^{30}$.

Even though it was possible to reduce $\mathrm{pH}$ values with the addition of $\mathrm{SiO}_{2}$ (Figure 8), the compressive strength did not improve. After addition of $\mathrm{SiO}_{2}$, the values of compressive strength were inferior to $1 \mathrm{MPa}$, even after 7 days of soaking in SBF (Figure 9), and only for $5 \mathrm{SiO}_{2}$, similar values to those of $\alpha$-TCP cement were achieved after 14 days.

The increase in mechanical strength of the cement occurs as a result of the formation of the interlocking of hydroxyapatite crystals precipitated after $\alpha$-TCP solubilization and in general, increases with immersion time in $\mathrm{SBF}^{31}$. However, since the particles of $\mathrm{SiO}_{2}$ act as nucleation sites for $\mathrm{C}_{3} \mathrm{~S}$ hydration and can cause blockage of the pores, which densifies the hydrating gel structure, $\alpha$-TCP dissolution and precipitation are delayed owing to the formation of a dense calcium silicate on the surface of $\alpha$-TCP particles, hence causing the initial low compressive strength. Moreover, although less significant, the increase of porosity caused by the degradation of the materials in early stages, also contributes to the decrease observed. For $5 \mathrm{SiO}_{2}$, with the increment in soaking time, and the advancement of the hydration reaction and crystal growth of CDHA, the compressive strength augmented.

The implantation of materials into living tissue causes wound and foreign body reactions. To predict the possible harmful effects of materials on the surrounding host tissues, it is important to gain information on the degradability of the implanted materials ${ }^{32}$. The relationship between the weight loss rate of the composites and the immersion time in SBF (Figure 10) shows that the weight of $\alpha$-TCP and $5 \mathrm{SiO}_{2}$ increased with time, whereas the weight of the composite cement decreased over time when the $\mathrm{SiO}_{2}$ content in the composite was $5 \%\left(10 \mathrm{SiO}_{2}\right)$. Moreover, adding $\mathrm{SiO}_{2}$ produces an increase in the degradation rates of composites; however, the degradation rate of $5 \mathrm{SiO}_{2}$ sample was lower than those of the composites containing only $\mathrm{C}_{3} \mathrm{~S}^{12}$ and the behavior observed was very similar to those of traditional CPCs.

Degradability of some CPCs is very slow both in vivo and in vitro ${ }^{33}$ and conventional CPCs usually often experience a mass gain after long soaking periods as a result of hydrolysis of $\alpha$-TCP or due to the formation of apatite on the surface of the samples. Considering the fact that the degradability is primarily governed by the chemical composition, the reason for the higher degradation rate of the $\alpha$-TCP/ $\mathrm{C}_{3} \mathrm{~S} / \mathrm{SiO}_{2}$ composites could be the higher solubility of the C-S-H as compared with CDHA. In addition, the dissolution of C-S-H and/or other phases could be larger than the amount of apatite deposited on the cement surface and formed due to the hydrolysis of $\alpha$-TCP, so the weight of samples decreased.

It is generally accepted that the in vitro cell-material interaction is a useful criterion in the evaluation of new biomaterials. Figure 11 shows the result of direct cytotoxicity test for composites against the PBMCs after incubation for 24 and 48 hours. Although differences were no statistical significant, composites containing $\mathrm{SiO}_{2}$ seem to be more cytotoxic than traditional $\alpha$-TCP. Furthermore, it was found that the viability of PBMCs showed a tendency towards a decrease in all compositions with aging probably due to the occurrence of 


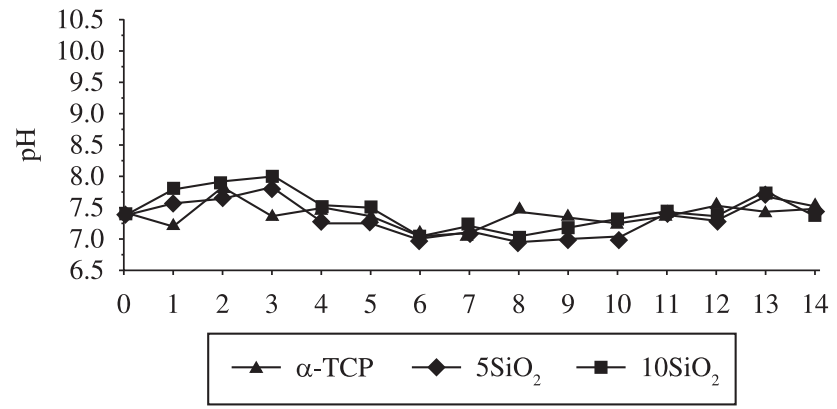

(a)

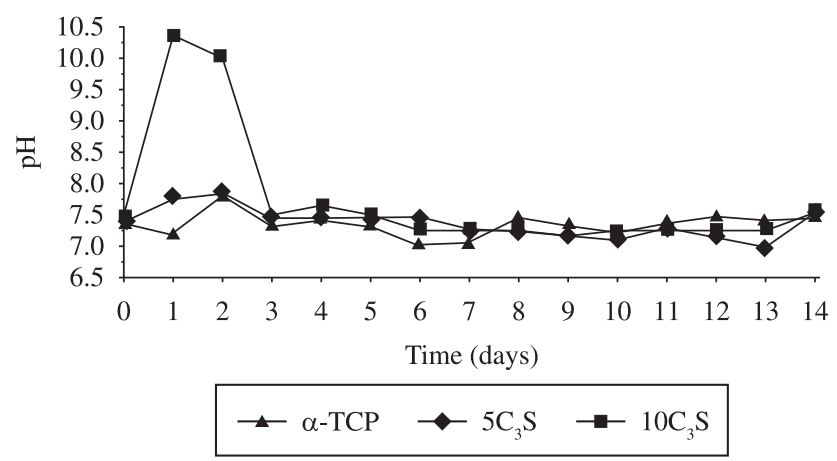

(b)

Figure 8. Changes in $\mathrm{pH}$ value of SBF soaked with a) $\alpha-\mathrm{TCP} / \mathrm{C}_{3} \mathrm{~S}$; and b) $\alpha-\mathrm{TCP} / \mathrm{C}_{3} \mathrm{~S} / \mathrm{SiO}_{2}$.

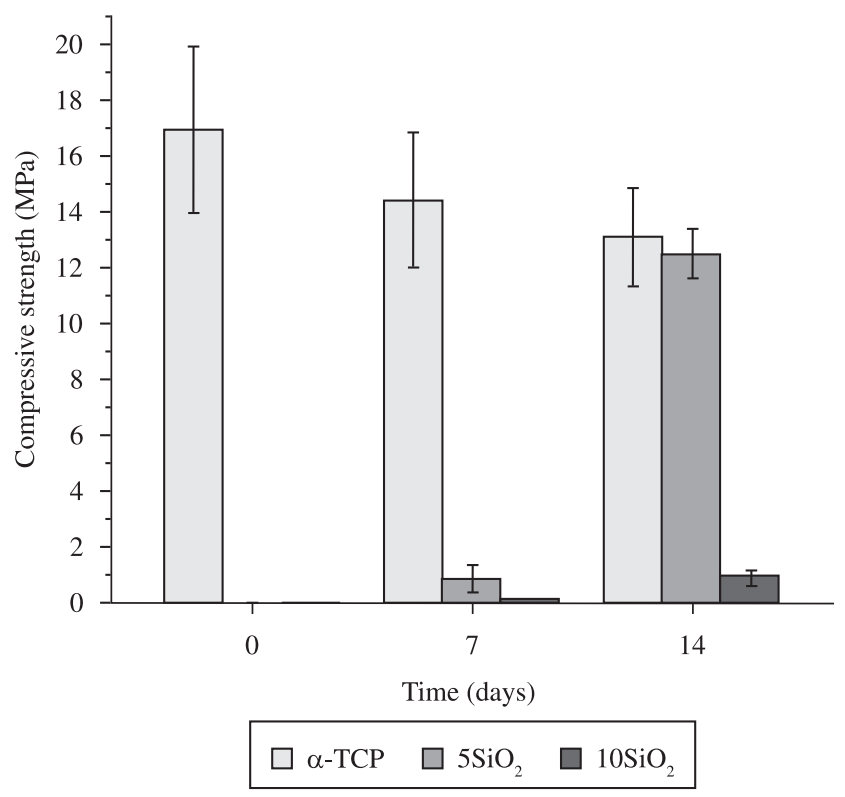

Figure 9. Compressive strength of the $\alpha$-TCP $\alpha-\mathrm{TCP} / \mathrm{C}_{3} \mathrm{~S} / \mathrm{SiO}_{2}$ composites after soaking in SBF.

some chemical transformations of the material in culture medium since after 7 days in aqueous media the pastes continues hydrating.

When only $\mathrm{C}_{3} \mathrm{~S}$ is added, compositions are less cytotoxic and more compatible than pure $\alpha$-TCP-based cement as a result of the dissolution of silicate ions present in $\alpha-\mathrm{TCP} / \mathrm{C}_{3} \mathrm{~S}$ pastes that stimulate cell proliferation ${ }^{34,35}$. With the presence of $\mathrm{SiO}_{2}$, more $\mathrm{C}-\mathrm{S}-\mathrm{H}$ is formed and more $\mathrm{HSiO}^{3-}$ is released during hydration which can

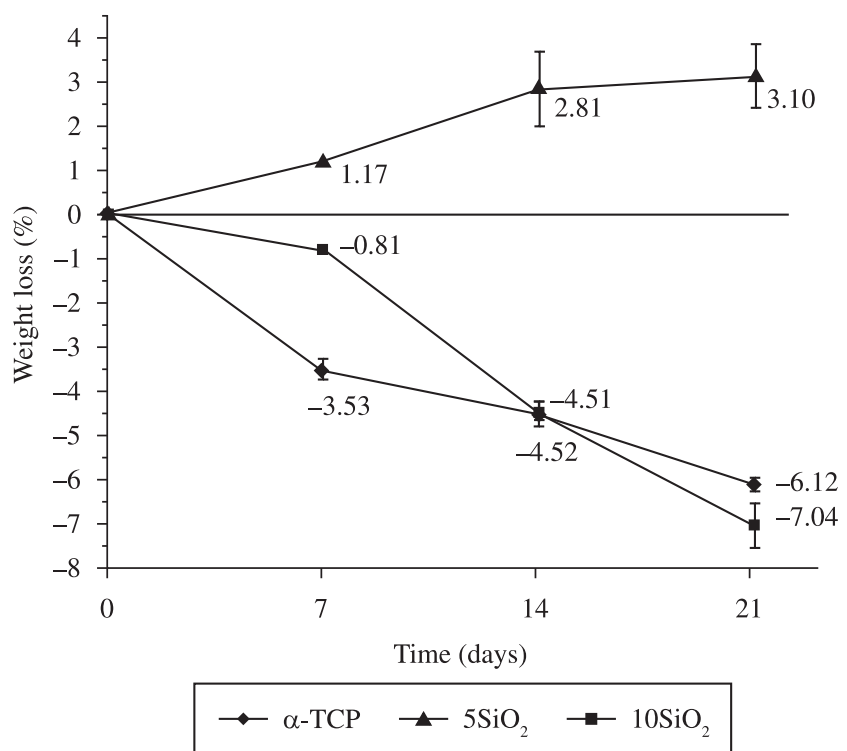

Figure 10. Weight loss of the $\alpha$-TCP and $\alpha-\mathrm{TCP} / \mathrm{C}_{3} \mathrm{~S} / \mathrm{SiO}_{2}$ composites after soaking in SBF.

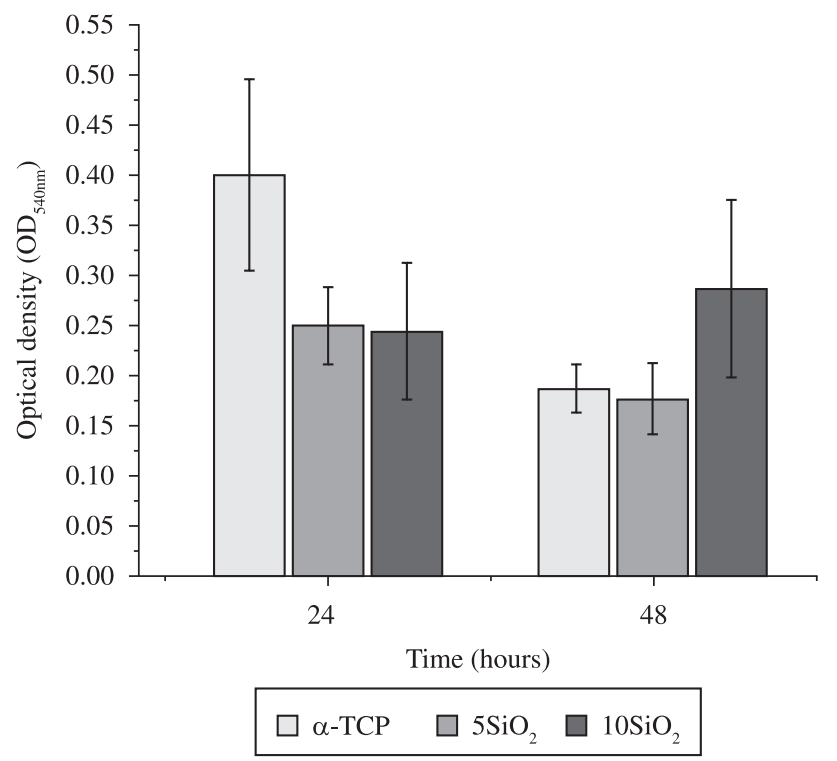

Figure 11. Cell viability of PBMCs on the different pastes after culturing for 24 and 48 hours.

accelerate the hydroxyapatite deposition on the surface and enhance biocompatibility. However, contrary to our expectations, the results showed a fall in cell viability maybe due to the higher solubility of compositions and the poor cohesion of the cement in the presence of $\mathrm{SiO}_{2}$ which may have masked the actual results.

\section{Conclusions}

The addition of $\mathrm{SiO}_{2}$ reduces local $\mathrm{pH}$ during $\mathrm{C}_{3} \mathrm{~S}$ hydrolysis and accelerates the hydration of $\mathrm{C}_{3} \mathrm{~S}$; however, it does not produce a noteworthy increase in compressive strength compared to conventional CPCs in the early stages as a result of the suppression of $\alpha$-TCP dissolution. Furthermore, the presence of $\mathrm{SiO}_{2}$ increases the 
degradability of cements and does not improve the biocompatibility of materials by reducing the cytotoxicity. Nevertheless, the $\alpha$-TCP/ $\mathrm{C}_{3} \mathrm{~S} / \mathrm{SiO}_{2}$ composites possess excellent bioactivity, as indicated by the early formation of bone-like apatite in SBF, being attributed to the presence of $\mathrm{C}_{3} \mathrm{~S}$ and not of $\mathrm{SiO}_{2}$.

\section{Acknowledgements}

This work was conducted with support from CAPES, the Brazilian Government entity dedicated to the training of human resources.

\section{References}

1. Brown WE and Chow LC. A new calcium phosphate water-setting cement. Cements Research Progress. 1986; 352-379.

2. LeGeros RZ, Chohayeb A and Shulman A. Apatitic calcium phosphates: possible dental restorative materials. Journal of Dental Research. 1982; 61:343.

3. Monma H. The hydration of alpha-tricalcium phosphate. Yogo-kyokaishi. 1976; 84: 209-213.

4. Ginebra MP, Boltong MG, Fernández E, Planell JA and Driessens FCM. Effect of various additives and temperature on some properties of an apatitic calcium phosphate cement. Journal of Material Science: Materials in Medicine. 1995; 6:612-616. http://dx.doi.org/10.1007/ BF00121286

5. Santos LA, Cristina de Oliveira L, Cristina da Silva E, Garcia R, Ortega A and Arruda A. Fiber Reinforced Calcium Phosphate. Artificial Organs. 2000; 24(3):212-216. http://dx.doi.org/10.1046/j.15251594.2000.06541.x

6. Yamamoto H, Niwa S, Hori M, Hattori T, Sawai K, Aoki S et al. Mechanical strength of calcium phosphate cement in vivo and in vitro. Biomaterials 1998; 19:1587-1591. http://dx.doi.org/10.1016/S01429612(97)00121-X

7. Dorozhkin S. Calcium orthophosphate cements and concretes. Materials. 2009; 2:221-291. http://dx.doi.org/10.3390/ma2010221

8. Ishikawa $\mathrm{K}$ and Asaoka K. Estimation of ideal mechanical strength and critical porosity of calcium phosphate cement. Journal of Biomedical Material Research. 1995; 29:1537-1543. http://dx.doi.org/10.1002/ jbm. 820291210

9. Lea FM. The Chemistry of Cement and concrete. London: Edward Arnold Ltd.; 1970.

10. Cárdenas LJ, Takeuchi A, Matsuya S and Ishikawa K. Effects of tricalcium silicate addition on basic properties of $\alpha$-tricalcium phosphate cement. Journal of the Ceramic Society of Japan. 2008; 116(1):83-7. http://dx.doi. org/10.2109/jcersj2.116.83

11. Morejon-Alonso L, Bareiro O, García Carrodeguas R and Santos LA. Development and characterization of new dual setting calcium phosphate cement. In vitro behavior. In: Anais do 54th Congresso Brasileiro de Cerâmicas; 2010; Foz de Iguaçu, Brazil. Foz de Iguaçu; 2010.

12. Morejon-Alonso L, Ferreira OJB, Garcia Carrodeguas R and Santos LA. Bioactive composite bone cement based on $\alpha$-tricalcium phosphate/ tricalcium silicate. Journal of Biomedical Material Research Part B. 2011. http://dx.doi.org/10.1002/jbm.b.31926

13. Zhao-Qi W and Young JF. The hydration of tricalcium silicate in the presence of colloidal silica. Journal of Materials Science.1984; 19:3477-3486. http://dx.doi.org/10.1007/BF02396922

14. Monma $\mathrm{H}$, Goto $\mathrm{M}$ and Kohmura T. Effect of additives on hydration and hardness of tricalcium phosphate. Gypsum Lime. 1984; 188:11-6.

15. Zhao W and Chang J. Sol-gel synthesis and in vitro bioactivity of tricalcium silicate powders. Material Letters. 2004; 58:2350-2353. http://dx.doi.org/10.1016/j.matlet.2004.02.045

16. American Society for Testing and Materials - ASTM. ASTM C266-89 A: Standart test method for time of setting of hydraulic-cement paste by Gillmore needles. 1995.
17. Kim HM, Miyazaki T, Kokubo $\mathrm{T}$ and Nakamura T. Revised Simulated Body Fluid. Key Engineering Material. 2001; 192-195:47-50. http://dx.doi.org/10.4028/www.scientific.net/KEM.192-195.47

18. Wang Ch, Yan M, Chang $\mathrm{H}$ and Ding S. Degradation behavior of porous calcium phosphates. Journal of Medical and Biological Engineering. 2003; 23(3):159-164.

19. Morejón-Alonso L, Ferrari MB, Camassola M, Garcia R and Santos LA. In vitro citotoxicity of a calcium phosphate-silicate composite bone cement. In: Proceedings of the 6th Congresso Latinoamericano de Órgãos Artificiais e Biomateriais; 2010; Gramado, Brazil. ABCM; 2010.

20. Morejón-Alonso L. Avaliação de cimentos ósseos de Fosfatos de Cálcio com adições de Aluminato e Silicato de Cálcio. [tese]. Porto Alegre: Universidade Federal do Rio Grande do Sul; 2011.

21. Morejon-Alonso L, Bareiro O, Garcia Carrodeguas R and Santos LA. In vitro bioactivity of a tricalcium silicate cement. In: Proceedings of the 53th Congresso Brasileiro de Cerâmicas; 2009; Guarujá, Brazil. São Paulo : Associação Brasileira de Cerâmica; 2009.

22. Ambard A and Mueninghoff L. Calcium Phosphate Cement: Review of mechanical and biological properties. Journal of Prosthodontics. 2006; 15:321-328. http://dx.doi.org/10.1111/j.1532-849X.2006.00129.x

23. Driessens FMC, Planell JA and Gil FG. Calcium phosphate bone cements. In: Wise DL et al., editors. Enciclopedic handbook of biomaterials and bioengineering. New York: Ed. Marcel Decker; 1996. part B: Aplications. p. 855-77.

24. International Organization for Standardization - ISO. ISO/FDIS 23317: Implants for surgery. In vitro evaluation for apatite-forming ability of implant materials. ISO; 2007.

25. Gil FJ, Padro's A, Manero JM, Aparicio C, Nilsson M and Planell JA. Growth of bioactive surfaces on titanium and its alloys for orthopaedic and dental implants. Materials Science and Engineering. 2002; C22:53-60.

26. Kokubo $\mathrm{T}$ and Takadama $\mathrm{H}$. How useful is $\mathrm{SBF}$ in predicting in vivo bone bioactivity? Biomaterials. 2006; 27: 2907-2915.

27. Kokubo T. Bioactive glass-ceramics: properties and applications. Ceramic Society of Japan. 1991; 99:965. http://dx.doi.org/10.2109/jcersj.99.965

28. Diamond S. Cement paste microstructure: An overview at several levels. In: Proceedings of the conference on Hydraulic Cement Pastes: Their Structure and Properties; 1977; Sheffield. Sheffield: University of Sheffield; 1977. p. 2-29.

29. Baltaky K, Jauberthie R, Siauciunas R and Kaminskas R. Influence of modification of $\mathrm{SiO}_{2}$ on the formation of calcium silicate hydrate. Materials Science-Poland. 2007; 25(3):663-670.

30. Fonseca PC and Jennings HM. The effect of drying on early-age morphology of C-S-H as observed in environmental SEM. Cement and Concrete Research. 2010; 40:1673-1680. http://dx.doi.org/10.1016/j. cemconres.2010.08.007

31. Kokubo T. Bioactive glass-ceramics: properties and applications. Ceramic Society of Japan. 1991; 99:965. http://dx.doi.org/10.2109/jcersj.99.965

32. Gruninger SE, Siew C, Chow LC, O'Young A, Ts' ao K and Brown WE. Evaluation of the biocompatibility of a new calcium-phosphate setting cement. Journal of Dental Research. 1984, 63:200.

33. Koerten HK and Van der Meulen J. Degradation of calcium phosphate ceramics. Journal of Biomedical Material Research. 1999; 44:78-86. http://dx.doi.org/10.1002/(SICI)1097-4636(199901)44:1\%3C78::AIDJBM9\%3E3.0.CO;2-6

34. Hollinger JO, Brekke J, Gruskin E and Lee D. Role of bone substitute. Clinical. Orthopedics. 1996; 324:55-66. http://dx.doi. org/10.1097/00003086-199603000-00008

35. Hench LL and West JK. Biological applications of bioactive glasses. Life Chemistry Reports. 1996; 13:187-241.

36. Zhao WY, Wang JY, Zhai WY, Wang Z and Chang J. The self-setting properties and in vitro bioactivity of tricalcium silicate. Biomaterials. 2005; 26:6113-6121. http://dx.doi.org/10.1016/j.biomaterials.2005.04.025 